\title{
SYSYEMIC LUPUS ERYTHEMATOSUS WITH MULTIPLE ORGAN DAMAGE
}

\author{
Andreea Alexandra Nicola ${ }^{1}$, Mădălina Dună ${ }^{1}$, Ioana Miler ${ }^{2}$, Nicoleta Petre ${ }^{2}$, \\ Denisa Predețeanu ${ }^{1}$ \\ "Sf. Maria" Clinical Hospital, Bucharest, Romania \\ ${ }^{2}$ Clinical Hospital of Nephrology "Dr. Carol Davila", Bucharest, Romania \\ Corresponding author \\ Andreea Alexandra Nicola \\ andreea.alexandra1102@gmail.com
}

\begin{abstract}
Systemic lupus erythematosus (SLE) is a heterogeneous rheumatic disease with various clinical manifestations and a multifactorial pathogenesis. Although the etiology of SLE is unknown, certain risk factors have been identified as promoters of an imbalance in the immune system with antibody formation and tissue damage secondary to the deposition of immune complexes. Women of childbearing age are predominantly affected, regardless of ethnicity.

SLE affects the kidneys in about $50 \%$ of patients, lupus nephritis (LN) being a major risk factor for overall morbidity and mortality. The lungs are commonly involved later in the course of the disease, pulmonary involvement in SLE being extremely varied. It includes along with pleuritis which is the most common manifestation, acute lupus pneumonitis, pulmonary vasculitis, pulmonary embolism, diffuse alveolar haemorrhage; opportunistic pulmonary infections or drug toxicity could be other pulmonary manifestations.

We present the case of a young woman with SLE complicated with lupus nephritis class $V$ and pulmonary infarction due to thromobosis of a pulmonary artery. It is a case of SLE with multiple organ damage and life-threatening complications that require interdisciplinary management and appropriate treatment.
\end{abstract}

Keywords: systemic lupus erythematosus, lupus nephritis, pulmonary cavity, thrombophilia.

\section{Abstract}

Lupusul eritematos sistemic (LES) este o afecțiune reumatică heterogenă, cu manifestări clinice variate și o patogenie multifactorială. Deși etiologia LES este necunoscută, anumiți factori de risc au fost identificați ca promotori ai unui dezechilibru în funcționarea sistemului imunitar, cu formare de anticorpi și leziuni tisulare secundare depunerii complexelor imune. Femeile aflate la vârsta fertilă sunt afectate în mod predominant, indiferent de etnie.

LES afectează rinichii la aproximativ 50\% dintre pacienți, nefrita lupică (LN) fiind un factor 


\section{INTERNAL}

\section{Clinical Cases}

major de risc pentru morbiditatea și mortalitatea generală. Ulterior, în cursul bolii, sunt implicați frecvent plămânii, afectarea pulmonară în LES fiind extrem de variată. Include alături de pleurită, care este cea mai frecventă manifestare, pneumonită lupică acută, vasculită pulmonară, embolie pulmonară, hemoragie alveolară difuză; infecțiile pulmonare oportuniste sau toxicitatea medicamentoasă pot fi alte manifestări pulmonare.

Prezentăm cazul unei tinere cu LES complicat cu nefrită lupus clasa $V$ și infarct pulmonar ca urmare a tromobozei unei artere pulmonare. Este un caz de LES cu leziuni multiple de organ și complicații amenințătoare de viață, care necesită management interdisciplinar și tratament adecvat.

Cuvinte cheie: lupus eritematos sistemic, nefrită lupică, cavitate pulmonară, trombofilie.

\section{Introduction}

Systemic lupus erythematosus (SLE) is a chronic multi-systemic autoimmune disease with unknown etiology and immune pathogenesis, that predominantly affects women of childbearing age $\mathrm{e}^{(1-3)}$. Multifactorial interaction between various genetic and environmental factors is probably involved, leading to a number of immunological abnormalities.

These include, along with a defective cellular apoptosis and an ineffective clearance of apoptotic materials and immune complexes, the complement deposition with tissue destruction. The loss of immune tolerance, increased antigenic load, activation of $T$ helper cells, defective B cell suppression, determine the production of pathogenic autoantibodies that mediate tissue inflammation and injury ${ }^{(2)}$.

The clinical course of SLE is highly variable and unpredictable and consists of periods of exacerbation (flares) characterized by a varied symptomatology and modified lab tests, alternating with periods of remission during which clinical manifestations are few or even missing. Clinical features range from mild joint and skin involvement to lifethreatening renal, pulmonary, hematologic, or central nervous system involvement.

Although SLE can affect any organ, in about $50 \%$ of patients it injures the kidneys, causing a glomerulopathy that can end in chronic kidney disease (CKD) or end-stage renal disease (ESRD) in $10-30 \%$ of the cases. Lupus nephritis (LN) is one of its most serious manifestations of SLE and is a major cause of 
morbidity and mortality. Moreover, the renal damage is the most important mortality predictor in these patients ${ }^{(4,5)}$.

Multiple factors contribute to the renal damage, including the complement, the autoantibodies, the treatment and also the genetics. Over the years, various clinical and laboratory parameters, such as proteinuria and autoantibodies, have been explored to indicate lupus nephritis severity assessment and prognosis ${ }^{(6-8)}$.

However, renal involvement is suggested by the presence of haematuria, proteinuria or decreased renal function, and requires confirmation by renal biopsy. The anatomopathological examination also gives valuable details about the pathologic patterns, establishes the activity and reversibility of renal injury, guides the therapeutic strategy and is an important provider of prognosis information such as treatment response and progression ${ }^{(8)}$.

The involvement of respiratory system in SLE includes all anatomic structures of the lungs: pleura, pulmonary parenchyma, pulmonary vasculature and respiratory muscles, while its severity ranges from asymptomatic pleural disease to acute respiratory failure. The most common features are pleuritis, interstitial lung disease and pulmonary embolism, the last one being usually related to antiphospholipid syndrome. Rare pulmonary complications are lupus pneumonitis, diffuse alveolar hemorrhage, shrinking lung syndrome and pulmonary arterial hypertension ${ }^{(9,10)}$. Cavitary lung lesions are extremely rare as primary lesion in lupic patients, but very few reports citing secondary causes leading to this kind of lesions are available. Various infections (bacterial, fungal or viral), embolism, or underlying vasculitis can evolve to cavity formation $^{(11,12)}$.
Haematological abnormalities in patients with SLE are frequent and diverse. Among the various cytopenias found in SLE, the most common one is the anemia. Although there are different causes for this disorder (inflammatory chronic disease, blood loss, kidney failure or drug-induced), autoimmune hemolytic anemia (AIHA) occurs in about $10 \%$ of SLE patients and is a serious complication. The warm type AlHA, mediated by IgG antibodies reacting in body temperature is the predominant type in patients with SLE. A very strict monitoring of anemia is essential, in order to establish the correct treatment $^{(13)}$.

Management of SLE with multiple organ involvement is a delicate, multidisciplinary matter, aiming the remission of signs and symptoms, prevention of organ damage and minimization of drugs side-effects.

Therapeutic strategies in SLE are currently still developing, predominantly involving immunomodulation and immunosuppression in order to achieve the lowest possible disease activity, considering that remission is a difficult target to achieve $\mathrm{e}^{(14,15)}$.

\section{Case report}

We present the case of a 28-year-old female patient diagnosed in 2014 with SLE with multiorgan damage (joint, cutaneous, hematological, immunological, renal and pulmonary), which is currently hospitalized in the rheumatology department for clinical and paraclinical re-evaluation and specialized treatment.

The rheumatic disease started in the spring of 2014 with arthritis of the small joints of the hands accompanied by a difficult grip for which the patient presented to a rheumatology clinic. Laboratory investigations performed at that time revealed mild anemia, 


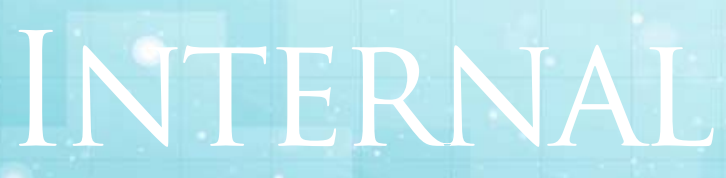

Clinical Cases.

hypocomplementemia, as well as positivity for lupus autoimmunity (total anti-nuclear antibodies, anti-double-stranded DNA, antiRo/SSA, and anti-La/SSB antibodies). Also rheumatoid factor and anticitrullinated protein antibodies (ACPAs) were positive, without typical bone changes for rheumatoid arthritis on the performed radiographs.

She was diagnosed with SLE by the rheumatologist in accordance with the 2012 Systemic Lupus International Collaborating Clinics (SLICC) criteria and treatment with hydroxychloroquine (HCQ), azathioprine (Imuran) and corticosteroids (methylprednisolone $24 \mathrm{mg} /$ day decreased to $4 \mathrm{mg} /$ day) was initiated. The patient did not accept the severity of her disease and interrupted repeatedly the recommended treatment, resorting to various alternative therapies such as bioenergy or apitherapy.

In June 2017, the patient presented for the first time in our rheumatology department for purpuric skin lesions on the lower limbs; it is important to highlight the fact that she was without treatment.

The disease was intensely active, with joint damage (synovitis), immunological disorder, hypocomplementemia and moderate anemia. During hospitalization, the first intravenous pulse of cyclophosphamide (400 $\mathrm{mg}$ ) was administered, and the resumption of hydroxychloroquine (400 mg/day) and corticotherapy in a progressively decreasing dose was indicated. From April 2018, the patient interrupted the recommended treatment on her own initiative, and in January 2019 she was urgently hospitalized in a pneumology service for cough with seromucous sputum with bloody streaks, fever, profuse sweating, significant weight loss (approximately $8 \mathrm{~kg}$ per a period of 2 months) and erythematous palpable skin lesions of the limbs (Figure 1 ).

The thoracic radiograph showed a cavitary image in the left lower lobe and the opacification of the costodiaphragmatic sinuses (predominantly right). Given the clinical presentation and the x-ray aspect, a tuberculous infection was suspected.

Subsequently, the bacteriological examinations performed for Mycobacterium tuberculosis were systematically negative and the infection was excluded. A native chest computed tomography (CT) scan revealed the left lung cavity, minimal pleural effusion and a subpleural alveolar consolidation in the right lower lobe which raised the suspicion of acute lupus pneumonitis (Figure 2). Although the cavity contained a small spherical mass inside, pulmonary aspergilloma was excluded due to its adhesion to the wall and lack of freedom to move within the cavity. Moreover, contrast CT scan determined the presence of a thrombus in the left lower lobe artery, tributary to the area of the cavity (Figure 3 ). 


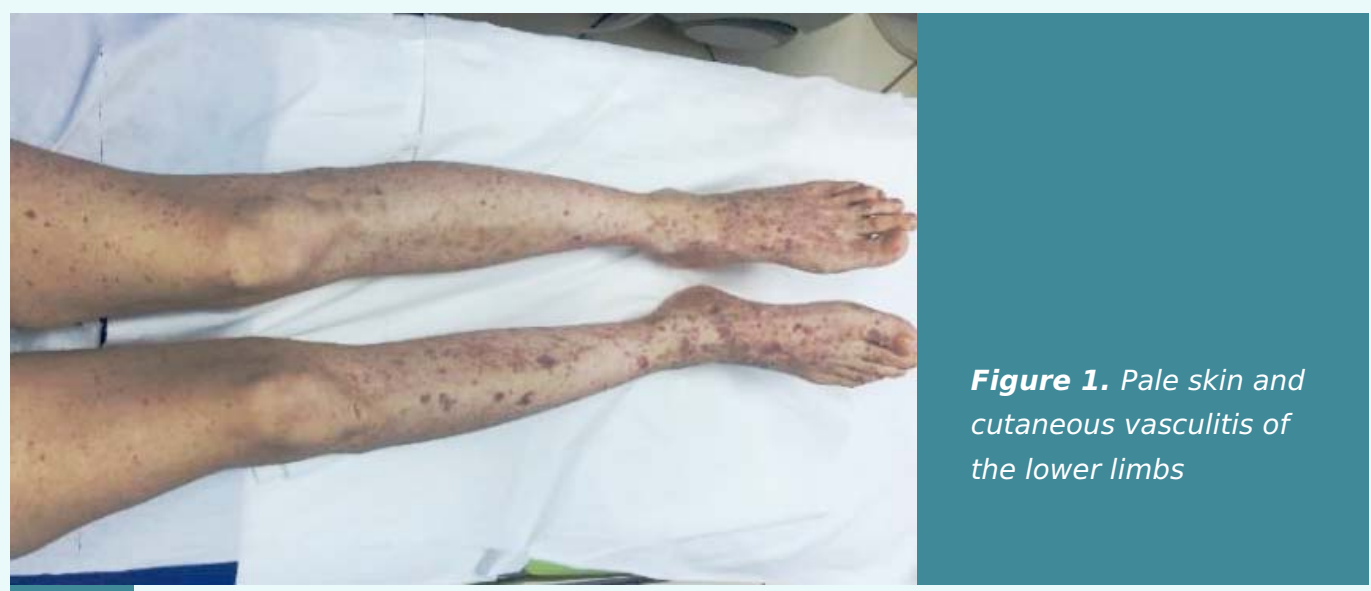

Figure 2. Native pulmonary CT: left lung cavity, minimal pleural effusion and a subpleural alveolar consolidation in the right lower lobe

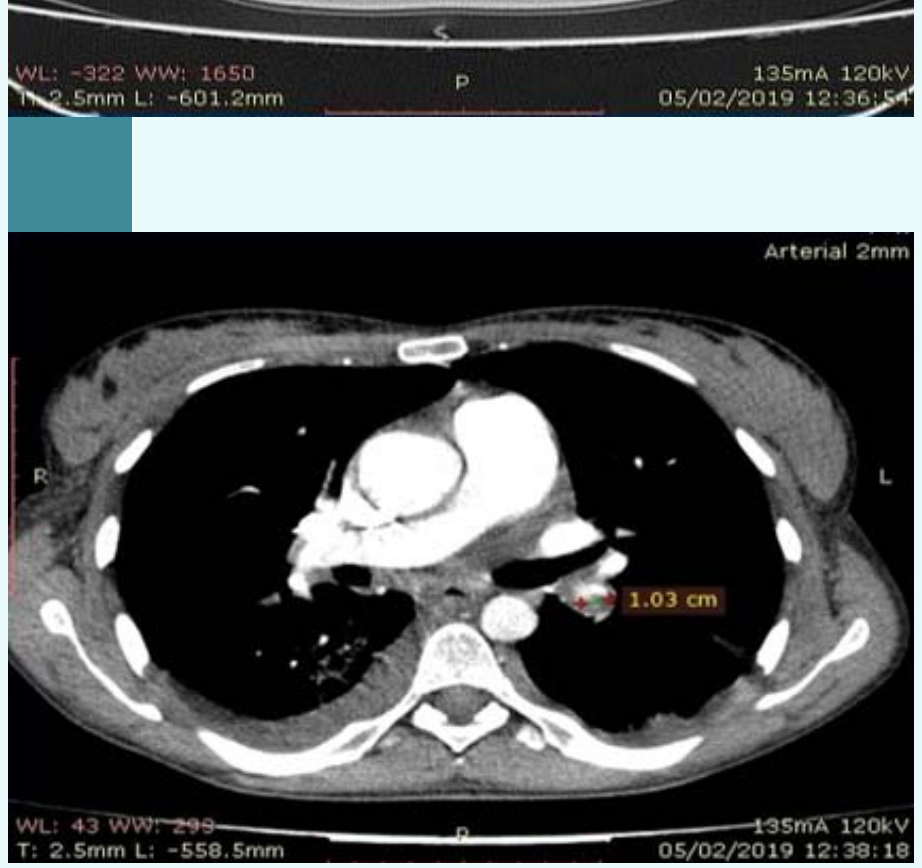

Figure 3. Contrast pulmonary CT: thrombus in the left lower lobe artery, right pleural effusion 


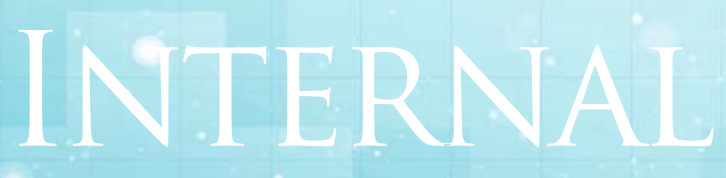

Clinical Cases.

CT images were highly suggestive of an excavated lung infarction with intensely positive D-dimers. At that moment, anticoagulant treatment with enoxaparin was initiated. For the suspicion of acute lupus pneumonitis and a progressive decrease in hemoglobin values $(4.8 \mathrm{~g} / \mathrm{dl})$, it was considered appropriate to transfer the patient to our rheumatology department.

Additional investigations performed in our clinic confirmed severe normochromic, normocytic, and normoregenerative anemia with positive direct Coombs test, suggestive for autoimmune hemolytic anemia. There were very low complement values ( $\mathrm{C} 3=42$ $\mathrm{mg} / \mathrm{dl}, \mathrm{C} 4=6.1 \mathrm{mg} / \mathrm{dl}$ ) and increased inflammatory markers.

Tests for antiphospholipid syndrome were negative, but a low level of $\mathrm{S}$ protein was found. Genetic investigations also revealed a heterozygous mutation in the PAl-1 gene. At the same time, the renal function was slightly altered (creatinine $=1.30 \mathrm{mg} / \mathrm{dl}$, asymptomatic hematuria, nephritic proteinuria). To exclude various sources of active bleeding, upper digestive endoscopy and colonoscopy were performed and multiple petechiae lesions were found in the sigmoid colon, but without active bleeding. Therefore, it was decided to continue anticoagulant therapy alongside with antibiotics.

Immunosuppressive therapy was initiated with cyclophosphamide intravenous pulse therapy (800 mg) and methylprednisolone (1 $\mathrm{g} /$ pulse), with the correction of severe anemia and the fading of vasculitic lesions.

Although the cavity remained approximately the same size, the resolution of the alveolar condensation areas was surprising, and the patient no longer had respiratory symptoms. As a treatment to follow, it was recommended to resume hydroxychloroquine and corticosteroid therapy with progressively lower doses, together with the oral anticoagulant (acenocoumarol) indefinitely.

The patient was given a total of 6 courses of cyclophosphamide (1st - $800 \mathrm{mg}$, the other five $-1 \mathrm{~g}$ ) over a period of 7 months.

Although she had a satisfactory response, returning periodically for reassessment and following the recommended treatment, renal function continued to deteriorate. As the problem of lupus nephropathy arises, in July 2019, a kidney puncture-biopsy is performed in the nephrology service. Changes compatible with class $\mathrm{V}$ lupus nephritis were highlighted on the bioptic material (Figure 4, Figure 5, Figure 6).

It was thus decided to follow the National Institutes of Health (NIH) lupus nephritis treatment program and maintain remission with mycophenolate mofetil (2 g/day, treatment initiated in September 2019) after the induction of remission with cyclophosphamide. Under the therapeutic regimen that included mycophenolate mofetil 2 g/day, 


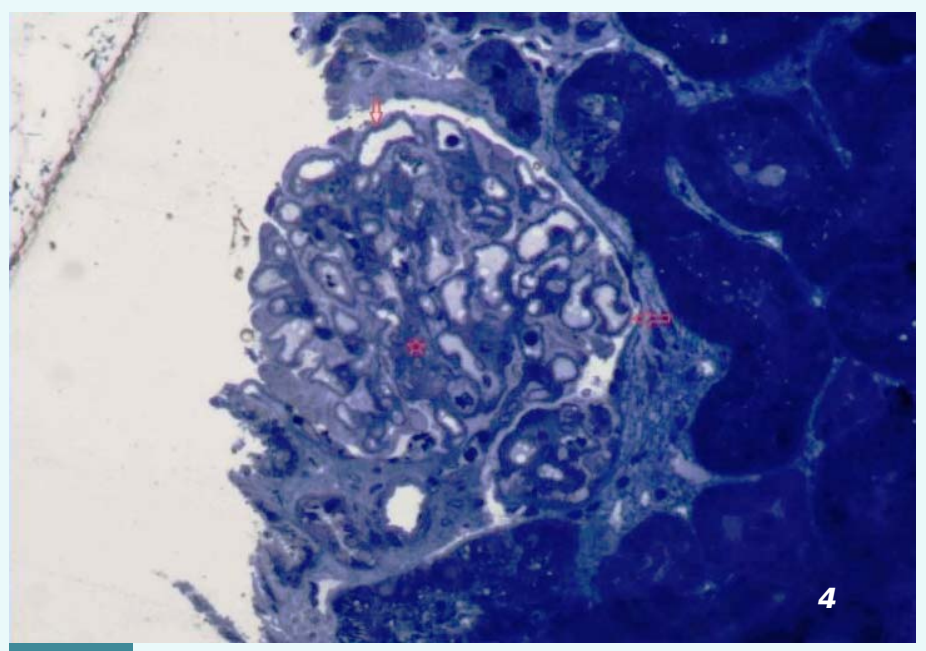

Figure 4. Renal Biopsy (Optical microscopy) - regular thickening and rigidity of the glomerular capillary walls (arrows) and segmental mesangial hypercellularity (star) - toluidine blue, (20X)

Figure 5. Renal Biopsy

(Immunofluorescence) - heavy ID of granular IgG, intramembranous and subepithelial (20x)

Figure 6. Renal Biopsy (Electronic Mycroscopy) subepithelial and intramembranous deposits (ranging from small to large and involving all the capillaries)

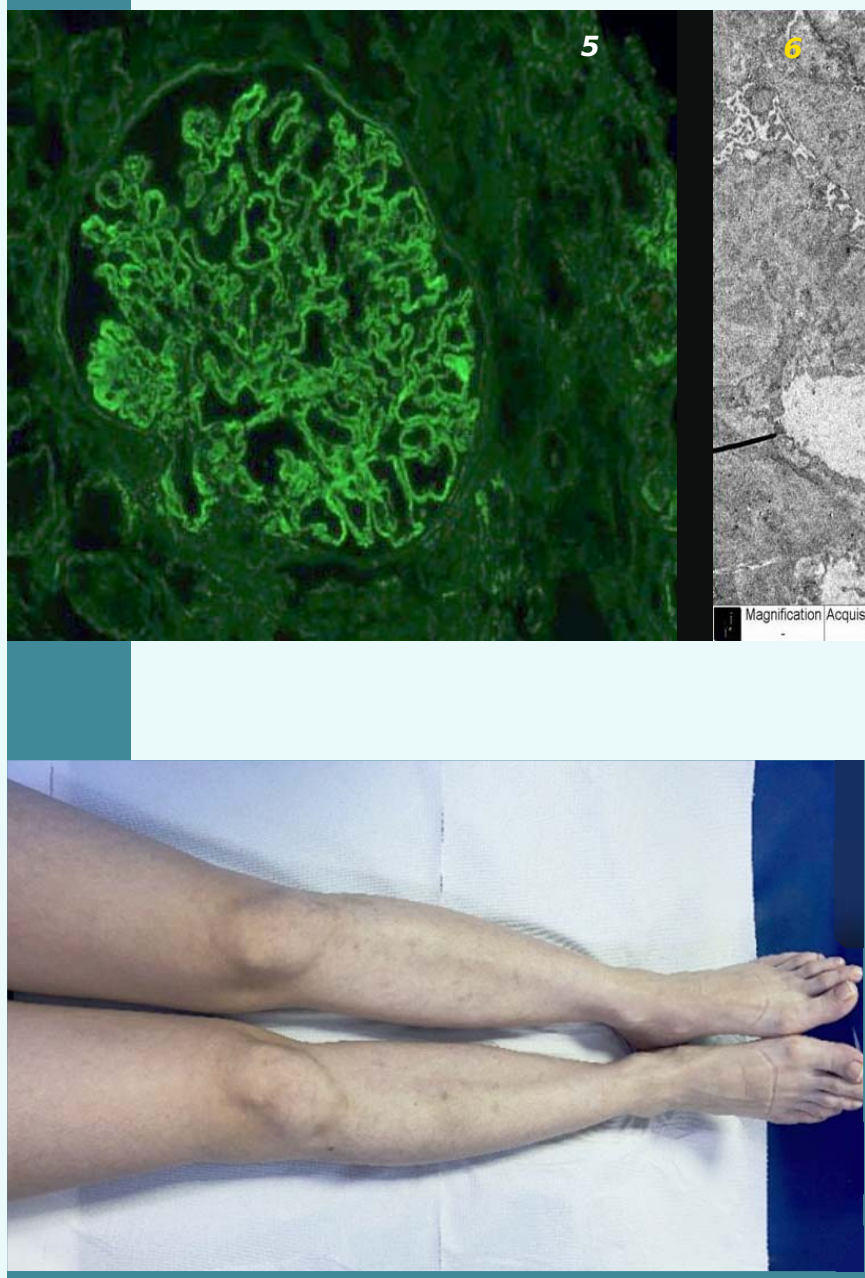

Figure 7. Favorable clinical evolution 


\section{INTERNAL MED}

Clinical Cases

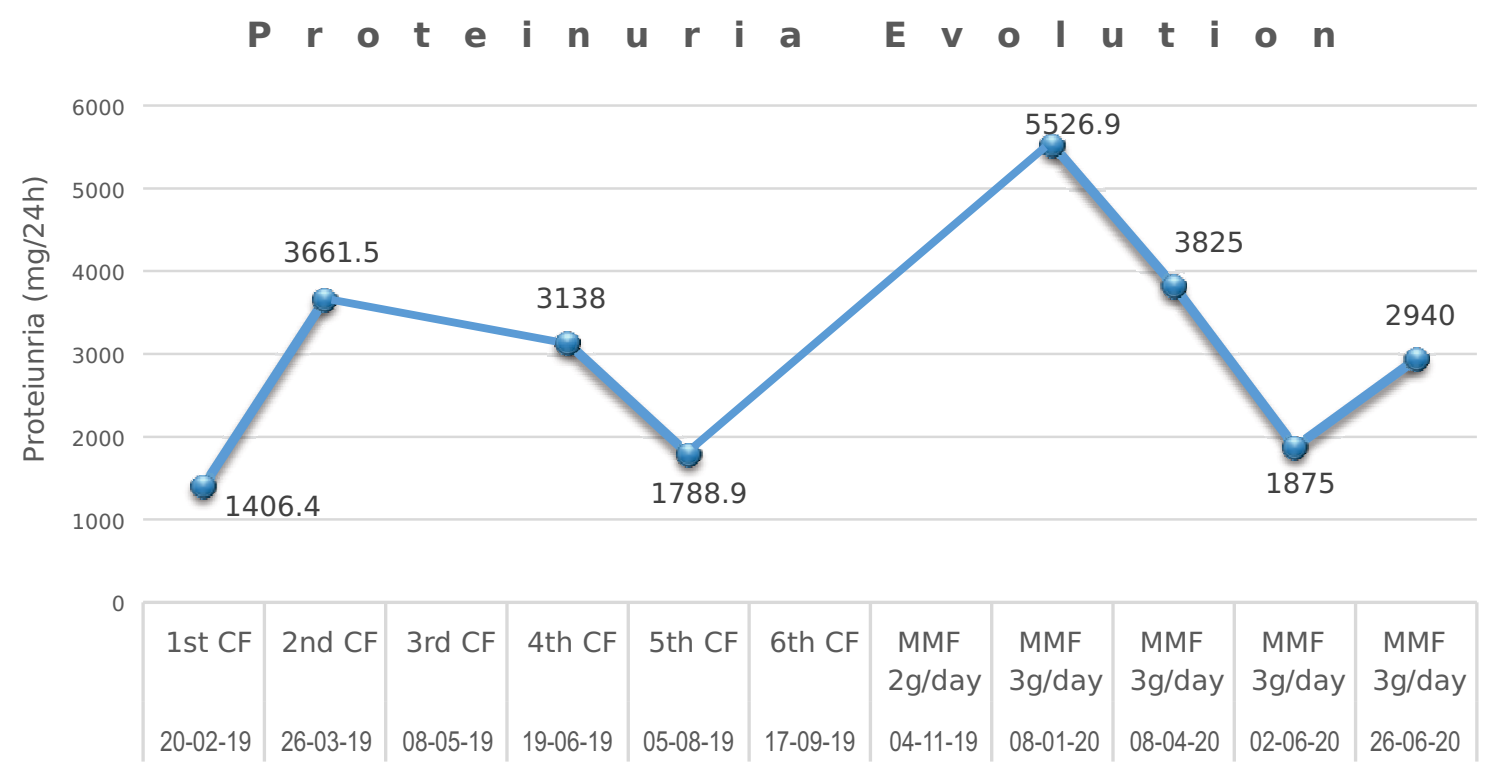

Figure 8. Proteinuria evolution

hydroxychloroquine $400 \mathrm{mg} / \mathrm{day}$ and lowdose corticosteroid therapy, the patient's proteinuria continued to be nephrotic (5.5 $\mathrm{g} / 24 \mathrm{~h}$ ), so the dose of mycophenolate mofetil was increased after about 4 months at 3 g/day.

At the current re-evaluation, the patient's condition is stable, without any clinical elements (Figure 7). Laboratory investigations show the persistence of mild anemia $(\mathrm{Hb}=9.2$ $\mathrm{g} / \mathrm{dL}$ ), low level of $\mathrm{C} 3$ complement ( $51 \mathrm{mg} / \mathrm{dL}$ ), the renal function being slightly improved (creatinine $=1.69 \mathrm{mg} / \mathrm{dl}$ ) with a decreased proteinuria (proteinuria $=2.94 \mathrm{~g} / 24 \mathrm{~h}$ ) (Figure $8)$. The radiological images show the disappearance of the cavity from the left lung, with the maintenance of fibro-calcareous sequelae.

It is decided at this time to continue immunosuppression with mycophenolate mofetil at a dose of $2.5 \mathrm{~g} /$ day due to an episode of non-selective loss of appetite accompanied by diarrhea and vomiting. At the same time, treatment with hydroxychloroquine $400 \mathrm{mg} /$ day, low-dose corticosteroid therapy (methylprednisolone $4 \mathrm{mg} /$ day), oral 
anticoagulant with vitamin $\mathrm{K}$ antagonists (acenocoumarol), but also conversion enzyme inhibitors and vitamin $D$ and $E$ supplements are maintained.

\section{Discussion}

This is a complex case of SLE with life-threating manifestations and complications. The presented patient had a severe flare of SLE (SELENA-SLEDAI score =16) with articular, immunological, serositic, hematological, renal and pulmonary involvement. Secondary, she had pulmonary thromboembolism complicated by excavated pulmonary infarction in the absence of antiphospholipid syndrome (APLS).

However, the patient presents primary thrombophilia elements that predispose to an increased risk of both arterial and venous thrombosis.

The causes of the increased thromboembolic risk in SLE patients are only partially understood. Arterial thrombotic events are more frequent than the venous thrombotic events and occur with an estimated probability of $5.1-8.5 \%$ within 5 years of diagnosis $^{(16,17)}$.

Antiphospholipid antibodies and accelerated atherosclerosis are already established risk factors for thrombotic events, but also abnormal interactions between platelets, leukocytes and vascular endothelium, as well as aberrant activation of the coagulation cascade can play a major role in the thrombosis mechanism ${ }^{(18,19)}$. Till this moment, very few studies on anticoagulant treatment with the new oral anticoagulants (NOAC) in thrombophilic patients exists. That is why long-term anticoagulant therapy with vitamin $\mathrm{K}$ antagonists (VKA) has been decided, although APS is absent.

AlHA is often associated with thrombocytopenia, LN, and central nervous system involvement ${ }^{(20-22)}$. In this case, the immunosuppressive treatment had a major effect and the levels of hemoglobin were almost normalized.

At this moment, the remission of the renal involvement is the main goal of the therapeutic management for this young woman. $\mathrm{LN}$ is the most common and severe complication of SLE.

According to the classification criteria developed in 2003 by the International Society of Nephrology / Renal Pathology Society (ISN / RPS), there are six histological classes of $\mathrm{LN}^{(23)}$. This classification criteria is necessary for the correct diagnosis, management and prognosis of the lupic patients. Treatment of $L N$ includes an initial induction phase of remission (6-12 months), followed by a longer maintenance phase of remission (2-3 years).

CYC and mycophenolate mofetil (MMF) are the most used immunosuppressive agents for the induction treatment. There are two protocols with CYC for the induction of remission: one with high doses of CYC in accordance with $\mathrm{NIH}$ and the other with low doses CYC (Euro-Lupus regimen).

The last one is preferred over high doses of CYC as it has comparable efficacy and lower risk of gonadal toxicity. MMF and high-dose CYC can be used for the severe forms of LN associated with increased risk of progression into end-stage renal disease. For this patient we preferred the NIH regimen, considering the rapid degradation of renal function, the presence of secondary arterial hypertension and the histopathological characteristics on the bioptic renal sample.

As maintenance therapy, MMF or AZA may be used, but the first one is associated with fewer relapses on long term. However, the choice depends on the agent used for induction phase and on patient characteristics (age, race and wish for pregnancy). Taking into 


\section{INTERNAL}

\section{Clinical Cases}

account the age of our patient and her will to procreate, we preferred MMF ( 2 g/day) with strict monitoring. In refractory or relapsing $L N$, rituximab (RTX) may be considered ${ }^{(14,24)}$. It is important to emphasize that all patients with LN should be treated with HCQ; there are clinical studies showing that HCQ treatment predicts complete renal remission over a 12month period in patients treated with MMF, especially for class $V$ of NL.

After 6 months of induction of remission therapy with CYC, the disease evolution was favorable.

However, the renal degradation remained a major problem, with high proteinuria $(5,5$ $\mathrm{g} / 24 \mathrm{~h})$ and increased creatinine level $(1,8$ $\mathrm{mg} / \mathrm{dL}$ ).

After other 6 months of remission maintenance therapy with immunosuppressive treatment (MMF), although the proteinuria had an important decrease $(1,6 \mathrm{~g} / 24 \mathrm{~h})$, it was never normalized. This case confirms that patients with LN class $V$ and nephrotic syndrome, frequently presents thromboembolic complications.

In case the proteinuria does not return to quasi-normal values and the renal function does not normalize, a repeated renal biopsy must be considered.

According to the guidelines, having an organthreatening disease which is refractory to standard immunosuppressive agents, RTX can be considered.

\section{Conclusions}

This is a severe case of SLE with multi-organ involvement, major differential diagnosis issues, and major treatment difficulties. Complications that have occurred during the course of the disease are rare, but lifethreatening. Rational therapeutic approach (corticosteroid, HCQ, CYC, MMF, anticoagulant treatment) was based on current theoretical knowledge and expertise of the physicians involved in the patient care. Strict monitoring of the patient with a complete clinical and paraclinical evaluation was important for a good outcome.

The favorable evolution of the patient was obtained through the correct management of the case in the conditions of interdisciplinarity between different specialties including rheumatology, nephrology, pneumology and radiology.

\section{References}

1. Tsokos GC. Systemic lupus erythematosus. N Engl J Med. 2011;365(22):2110-2121. doi:10.1056/ NEJMra1100359

2. Mok CC, Lau CS. Pathogenesis of systemic lupus erythematosus. J Clin Pathol. 2003;56(7):481-490. doi:10.1136/jcp.56.7.481

3. Siegel M, Lee SL. The epidemiology of systemic lupus erythematosus. Semin Arthritis Rheum. 1973;3(1):1-54. doi:10.1016/0049-0172(73)90034-6

4. Almaani S, Meara A, Rovin BH. Update on Lupus Nephritis. Clin J Am Soc Nephrol. 2017;12(5):825-835. doi:10.2215/CJN.05780616

5. Ward MM. Changes in the Incidence of End-stage Renal 
Disease Due to Lupus Nephritis, 1982-1995. Arch Intern Med. 2000;160(20):3136-3140. doi:10.1001/ archinte.160.20.3136

6. Tang $Y$, Zhang $W$, Zhu $M$, et al. Lupus nephritis pathology prediction with clinical indices. Sci Rep. 2018;8(1):10231. Published 2018 Jul 6. doi:10.1038/ s41598-018-28611-7

7. Haddon DJ, Diep VK, Price JV, et al. Autoantigen microarrays reveal autoantibodies associated with proliferative nephritis and active disease in pediatric systemic lupus erythematosus. Arthritis Res Ther. 2015;17(1):162. Published 2015 Jun 17. doi:10.1186/ s13075-015-0682-6

8. Yu F, Haas M, Glassock R, Zhao MH. Redefining lupus nephritis: clinical implications of pathophysiologic subtypes. Nat Rev Nephrol. 2017;13(8):483-495. doi:10.1038/nrneph.2017.85

9. Murin S, Wiedemann HP, Matthay RA. Pulmonary manifestations of systemic lupus erythematosus. Clin Chest Med. 1998;19(4):641-viii. doi:10.1016/s02725231(05)70108-8

10. Kamen DL, Strange C. Pulmonary manifestations of systemic lupus erythematosus. Clin Chest Med. 2010;31(3):479-488. doi:10.1016/j.ccm.2010.05.001

11. Webb WR, Gamsu G. Cavitary pulmonary nodules with systemic lupus erythematosus: differential diagnosis. AJR Am J Roentgenol. 1981;136(1):27-31. doi:10.2214/ajr.136.1.27

12. Ryu JH, Swensen SJ. Cystic and cavitary lung diseases: focal and diffuse. Mayo Clin Proc. 2003;78(6):744-752. doi:10.4065/78.6.744

13. Newman K, Owlia MB, El-Hemaidi I, Akhtari M. Management of immune cytopenias in patients with systemic lupus erythematosus - Old and new. Autoimmun Rev. 2013;12(7):784-791. doi:10.1016/ j.autrev.2013.02.001

14. Fanouriakis A, Kostopoulou M, Alunno A, et al. 2019 update of the EULAR recommendations for the management of systemic lupus erythematosus. Annals of the Rheumatic Diseases 2019;78:736-745.

15. Van Vollenhoven RF, Mosca M, Bertsias G, et al. Treatto-target in systemic lupus erythematosus: recommendations from an international task force. Ann Rheum Dis. 2014;73(6):958-967. doi:10.1136/ annrheumdis-2013-205139

16. Sarabi ZS, Chang E, Bobba $R$ et al. Incidence rates of arterial and venous thrombosis after diagnosis of systemic lupus erythematosus. Arthritis Rheum 2005;53:60912.

17. Mok CC, Tang SS, To CH, Petri M. Incidence and risk factors of thromboembolism in systemic lupus erythematosus: a comparison of three ethnic groups. Arthritis Rheum 2005;52:277482

18. Bazzan, M., Vaccarino, A. \& Marletto, F. Systemic lupus erythematosus and thrombosis. Thrombosis J 13, 16 (2015). doi:10.1186/s12959-015-0043-3

19. Ramirez GA, Efthymiou M, Isenberg DA, Cohen $H$. Under crossfire: thromboembolic risk in systemic lupus erythematosus. Rheumatology (Oxford). 2019;58(6) :940-952. doi:10.1093/rheumatology/key307

20. Sultan SM, Begum S, Isenberg DA. Prevalence, patterns of disease and outcome in patients with systemic lupus erythematosus who develop severe haematological problems. Rheumatology (Oxford). 2003;42(2):230-234. doi:10.1093/ rheumatology/ keg069

21. Kokori SI, loannidis JP, Voulgarelis M, Tzioufas AG, Moutsopoulos HM. Autoimmune hemolytic anemia in patients with systemic lupus erythematosus. Am J Med. 2000;108(3):198-204. doi:10.1016/s0002-9343(99) 00413-1

22. Nossent JC, Swaak AJ. Prevalence and significance of haematological abnormalities in patients with systemic lupus erythematosus. Q J Med. 1991;80(291):605-612.

23. Markowitz GS, D'Agati VD. The ISN/RPS 2003 classification of lupus nephritis: an assessment at 3 years. Kidney Int. 2007;71(6):491-495. doi:10.1038/ sj.ki.5002118

24. Houssiau FA, Vasconcelos C, D'Cruz D, et al. Immunosuppressive therapy in lupus nephritis: the EuroLupus Nephritis Trial, a randomized trial of low-dose versus high-dose intravenous cyclophosphamide. Arthritis Rheum. 2002;46(8):2121-2131. doi:10.1002/ art.10461 